Aletria, Belo Horizonte, v. 31, n. 2, p. 343-363, 2021

(c) (1)

\title{
A escrita infamiliar a partir do olhar de duas crianças
}

\section{The Uncanny Writing from the Perspective of Two Children}

\author{
Davi Andrade Pimentel \\ Universidade Federal do Rio de Janeiro (UFRJ), Rio de Janeiro, Rio de Janeiro / Brasil \\ davi_a_pimentel@yahoo.com.br \\ http://orcid.org/0000-0001-5519-3792
}

Resumo: A partir da leitura do livro $O$ infamiliar [Das Unheimliche] (1919), de Sigmund Freud, este artigo busca analisar a construção da palavra poética em seu constante confrontamento com o infamiliar, que se constitui como a base inventiva e pulsional do escritor enquanto personagem-criança de seus próprios textos. Esta análise se fundamenta no estudo de um fragmento do livro L'écriture du désastre, de Maurice Blanchot, intitulado "(Uma cena primitiva?)", e no livro Poeminha em língua de brincar, de Manoel de Barros. Entre os dois escritores trava-se um progressivo diálogo acerca da potencialidade inventiva da criança em criar e/ou imaginar a partir do infamiliar que, para além de uma cena ou de um ato específico que lhe provocará um possível trauma, se encontra na própria palavra poética. Nessa perspectiva, através do olhar infantil, propomos refletir como se apresenta o infamiliar no poema de Manoel de Barros e na escrita-poética de Maurice Blanchot.

Palavras-chave: infamiliar; desastre; Manoel de Barros; Maurice Blanchot; Sigmund Freud.

Abstract: Considering the Reading of Sigmund Freud's O infamiliar [Das Unheimliche] (1919), this article aims to analyze the construction of the poetic word in its constant confrontation with the uncanny, that is constituted as the inventive and drive basis of the writer as a child-character of his own texts. This analysis is based on the study of a fragment of Maurice Blanchot's L'écriture du désastre, entitled "(A primitive scene?)" and on Manoel de Barros's Poeminha em língua de brincar. A progressive dialogue takes place between these two authors regarding the inventive potential of the child in creating and/or imagining something from the uncanny, which beyond a scene or a 
specific act that may cause a possible trauma can be found on the poetic word itself. Thus, through the child perspective, a reflection of how the uncanny appears on Manoel de Barros's poem and on Maurice Blanchot's poetic-writing is proposed.

Keywords: uncanny; disaster; Manoel de Barros; Maurice Blanchot; Sigmund Freud.

\section{Considerações iniciais}

Neste artigo, que será dividido em dois momentos, "Olhar, verbo infamiliar" e "O arrebatamento pela via do infamiliar", dois textos literários serão essenciais para o seu desenvolvimento: o poema "Poeminha em língua de brincar" (2019), presente no livro de mesmo nome, de Manoel de Barros; e o fragmento poético em prosa "(Uma cena primitiva?)"(1980), presente no livro L'écriture du désastre, ${ }^{1}$ de Maurice Blanchot. Como proposta para uma melhor compreensão deste artigo, cito a seguir, na íntegra, os dois textos:

Texto I: “Poeminha em língua de brincar”, de Manoel de Barros.

Ele tinha no rosto um sonho de ave extraviada.

Falava em língua de ave e de criança.

Sentia mais prazer de brincar com as palavras do que de pensar com elas.

Dispensava pensar.

Quando ia em progresso para árvore queria florear.

Gostava mais de fazer floreios com as palavras do que de fazer ideias com elas.

Aprendera no Circo, há idos, que a palavra tem que chegar ao grau de brinquedo para ser séria de rir.

Contou para a turma da roda que certa rã saltara sobre uma frase dele e que a frase nem arriou.

Decerto não arriou porque não tinha nenhuma palavra podre nela.

\footnotetext{
${ }^{1}$ Todas as traduções das obras em francês citadas neste artigo são de minha autoria.
} 
Nisso que o menino contava a estória da rã na frase entrou uma Dona de nome Lógica da Razão.

A Dona usava bengala e salto alto.

De ouvir o conto da rã na frase a Dona falou: Isso é Língua de brincar e é idiotice de criança pois frases são letras sonhadas, não têm peso nem consistência de corda para aguentar uma rã em cima dela.

Isso é língua de Raiz - continuou.

É Língua de Faz de conta é Língua de brincar!

Mas o garoto que tinha no rosto um sonho de ave extraviada também tinha por sestro jogar pedrinhas no bom senso.

E jogava pedrinhas:

disse que ainda hoje vira a nossa Tarde sentada sobre uma lata ao modo que um bem-te-vi sentado na telha.

Logo entrou a Dona Lógica da Razão e bosteou: Mas lata não aguenta uma Tarde em cima dela, e ademais a lata não tem espaço para caber uma Tarde nela! Isso é Língua de brincar é coisa-nada. O menino sentenciou:

Se o Nada desaparecer a poesia acaba.

E se internou na própria casca ao jeito que o jabuti se interna. (BARROS, 2019, p. 7-32)

Texto II: “(Uma cena primitiva?)”, de Maurice Blanchot.

- (Uma cena primitiva?) Vocês que vivem bastante, próximos de um coração que não bate mais, suponham, suponham-no: a criança - ele tem sete anos, oito anos talvez? - de pé, abrindo a cortina e, através da vidraça, observando. O que ele vê, o jardim, as árvores de inverno, a parede de uma casa: enquanto vê, sem 
dúvida à maneira de uma criança, seu espaço de jogo, ele se cansa e lentamente olha para cima em direção ao céu comum, com as nuvens, a luz cinzenta, o dia sem graça e sem horizonte.

O que se passa em seguida: o céu, o mesmo céu, de repente aberto, absolutamente escuro e absolutamente vazio, revelando (como pela vidraça quebrada) uma tal ausência como se tudo já estivesse lá desde sempre e para sempre perdido, a tal ponto que nela se afirma e se dissipa o saber vertiginoso que nada é o que existe, e sobretudo nada existe para além dela. O inesperado dessa cena (sua característica interminável) é o sentimento de felicidade que logo submerge a criança, a alegria devastadora que ele somente poderá testemunhar pelas lágrimas, uma profusão sem fim de lágrimas. Acredita-se em uma aflição da criança, procurase consolá-la. Ele não diz nada. Ele viverá de agora em diante no segredo. Ele não chorará mais.

(BLANCHOT, 1980, p. 117, grifos do autor, tradução nossa) $)^{2}$

\section{Olhar, verbo infamiliar}

O olhar. O olhar que cava e desenterra a palavra poética recalcada na palavra cotidiana. O olhar que testemunha $o$ acontecimento. O olhar (sobre o) in-familiar. Olhos: órgãos sensitivos, de sensibilidade que desvelam o des-conhecido, que tornam, ou não, o selvagem em doméstico. O olhar da criança e, mais tarde, o olhar do adulto: olhar(es)

\footnotetext{
${ }^{2}$ No original:

- "(Une scène primitive?) Vous qui vivez plus tard, proches d'un cour qui ne bat plus, supposez, supposez-le: l'enfant-a-t-il sept ans, huit ans peut-être? - debout, écartant le rideau et, à travers la vitre, regardant. Ce qu'il voit, le jardin, les arbres d'hiver, le mur d'une maison: tandis qu'il voit, sans doute à la manière d'un enfant, son espace de jeu, il se lasse et lentement regarde en haut vers le ciel ordinaire, avec les nuages, la lumière grise, le jour tenre et sans lointain.

Ce qui se passe ensuite: le ciel, le même ciel, soudain ouvert, noir absolument et vide absolument, révélant (comme par la vitre brisée) une telle absence que tout s'y est depuis toujours et à jamais perdu, au point que s'y affirme et s'y dissipe le savoir vertigineux que rien est ce qu'ily $a$, et d'abord rien au-delà. L'inattendu de cette scène (son trait interminable), c'est le sentiment de bonheur qui aussitôt submerge l'enfant, la joie ravageante dont il ne pourra témoigner que par les larmes, un ruissellement sans fin de larmes. On croit à un chagrin d'enfant, on cherche à le consoler. Il ne dit rien. Il vivra désormais dans le secret. Il ne pleurera plus."
} 
em desvio, em devir, sujeitos a uma diferenciação capaz de colocá-los em polos opostos, porém, justapostos, uma vez que esse(s) olhar(es) se origina $(\mathrm{m})$ de um único ponto, a fabricação inconsciente do desejo:

Mas quem conhece a vida psíquica das pessoas sabe que nada é mais difícil do que renunciar a um prazer que um dia foi conhecido. No fundo, não poderíamos renunciar a nada, apenas trocamos uma coisa por outra; o que parece ser uma renúncia é, na verdade, uma formação substitutiva ou um sucedâneo. (FREUD, 2018, p. 55).

O desvio da moção do desejo - do olhar externo: a brincadeira explorativa da criança, com seus brinquedos e jogos, com o seu "florear" e "brincar", na construção de um mundo próprio que tem como seu contrário a realidade do mundo adulto; para o olhar interno: já que ao adulto não cabe mais a brincadeira infantil, resta-lhe substituir o desejo de brincar pelo de fantasiar, construir internamente, nas palavras de Freud (2018), castelos de ar em seus sonhos diurnos. Esses olhar(es) em desvio partilham não apenas de um desejo primário, mas também de um medo originário, o medo de que os olhos sejam subtraídos:

Ao contrário, a experiência psicanalítica nos lembra que uma angústia assustadora das crianças é o medo de machucar ou perder os olhos. Em muitos adultos, essa angústia permanece, e eles não temem tanto ferir outro órgão quanto os olhos. (FREUD, 2019, p. 61)

Os homens devotam generosa importância aos olhos: "Em tudo e em todo lugar meus próprios olhos bastam para me controlar, para me pôr de sobreaviso em relação a mim mesmo. Ninguém me vigia tão bem nem mais temo eu do que escandalizar" (MONTAIGNE, 2016, p. 149).

Édipo, certamente, se oporia à fala de Montaigne. Inconscientemente, ${ }^{3}$ ele mata o seu pai, casa-se com a sua mãe e gera filhos(as)irmãos(ãs), não escapando assim de seu destino, proferido pelo oráculo

\footnotetext{
${ }^{3}$ A interpretação, neste artigo, de que Édipo age inconscientemente parte de uma interpretação freudiana. Como nos lembra Elisabeth Roudinesco (2019, p. 30), em Dicionário amoroso da psicanálise, "entre seus grandes modelos de genealogia do parentesco, ele [Freud] escolheu dois personagens primordiais: Édipo e Hamlet. A seu ver, o primeiro encarna o teatro do inconsciente, o que permanece desconhecido do sujeito, enquanto o segundo remete à consciência culpada".
} 
ao seu pai biológico, Laio - destino para a morte, inescapável: tanto à morte ao nascer, caso o servo realmente o sacrificasse seguindo as ordens do rei Laio, quanto à morte já adulto, quando o velho Edipo é atingido pelo raio de Zeus e tragado pela cratera resultante desse raio fulminante. Em um momento da tragédia, Jocasta diz a Édipo:

A arte da profecia - deves sabê-lo - / não interfere nas questões humanas. / Sucintamente posso demonstrá-lo: / outrora Laio recebeu um oráculo / - senão do próprio Apolo, de seus próceres -, / segundo o qual a Moira lhe traria / a morte pelas mãos de um filho nosso. (SÓFOCLES, 2016, p. 72)

Contudo, como saberemos logo depois, através do mensageiro e do servo, a profecia já se realizara, pois a criança, Édipo, dada à morte foi salva - ou não. Os olhos de Édipo não o controlaram, não o puseram de sobreaviso e não foram o bastante para revogar o seu destino já de antemão traçado pelos deuses. Como consequência de seus atos, por ter infringido a lei dos homens e por ter mantido sem o saber uma relação incestuosa com a mãe, Édipo se priva de seu bem mais precioso, os seus olhos. Essa privação é bastante significativa para o que pretendo apresentar neste artigo. Édipo, arriscando uma certa compensação para o seu ato grotesco, se desfaz de seus olhos, arranca-os e entrega-os ao destino como moeda de troca: "Ele arrancou das vestes de Jocasta / os fechos de ouro com que se adornava, / e, erguendo as mãos, o círculo dos olhos golpeou" (SÓFOCLES, 2016, p. 101). Freud (2019), em $O$ infamiliar, dirá que o ato de Édipo seria uma espécie de punição pela castração. $\mathrm{O}$ medo de perder o pênis é substituído, segundo o psicanalista, pelo medo de perder os olhos ou, com menos frequência, pelo medo de perder outro membro qualquer do corpo. Esse medo da castração se dá tanto nos sonhos quanto nas fantasias dos pacientes.

Já nos mitos da civilização, a punição pela castração pode deixar o plano da fantasia ou do onírico para ser um ato da ordem da materialização, como em Édipo Rei, de Sófocles. Tanto Freud quanto Montaigne e Sófocles destacam a importância dos olhos, ou seja, do olhar para o homem. O olhar como o signo máximo da psique, da inteligência e da criatividade do homem, capaz de diferenciá-lo dos demais entes. No entanto, os olhos nos levam, igualmente a Édipo, a três caminhos: o primeiro, para o desvelamento; o segundo, para a ocultação; e o terceiro, para o poético. Esses caminhos, por vezes, formam uma complexa 
encruzilhada, na qual, eventualmente, nos perdemos, o que provoca em nós uma sensação de infamiliaridade. Neste momento, atenho-me ao significado figurado do verbo olhar: maneira de ver e de interpretar. Em Poeminha em língua de brincar, de Manoel de Barros, a criança-poeta, ${ }^{4}$ na décima primeira estrofe do poema, diz à turma da roda: "E [o garoto] jogava pedrinhas: / disse que ainda hoje vira a nossa Tarde sentada / sobre uma lata ao modo que um bem-te-vi sentado / na telha" (BARROS, 2019, p. 26). Na leitura desses versos, o adulto, iniciado ou não na poesia, acaba por ser invadido por uma sensação de infamiliaridade. Por quê? $\mathrm{O}$ que há na interpretação da criança-poeta, no seu ver o mundo, que descentra a perspectiva do adulto, a ponto de a Dona Lógica da Razão ter que intervir para deixar claro o limite que supostamente existe entre a linguagem infantil e a adulta?

A resposta está na própria linguagem e em sua desconstrução efetuada pela criança-poeta. Ao criar o seu próprio mundo, como o poeta, a partir da linguagem cotidiana, mas deslocando-a, descentrando-a e desmontando-a a fim de que ela possa inaugurar uma nova ordem linguística e, consequentemente, imaginativa, a criança-poeta pode ressignificar a palavra tarde, dando-lhe uma nova configuração, não mais de advérbio ou de substantivo comum feminino, e sim de substantivo próprio, transformando-a em um ente capaz de se sentar em uma lata assim como o bem-te-vi em uma telha: "Talvez devêssemos dizer: toda criança brincando se comporta como um poeta, na medida em que ela cria seu próprio mundo, melhor dizendo, transpõe as coisas do seu mundo para uma nova ordem, que lhe agrada" (FREUD, 2018, p. 54). Ao entrar no espaço poético, a linguagem cotidiana perde a pretensa objetividade adquirida no mundo real, o seu "bom senso", não por menos a criançapoeta lhe joga pedrinhas, para que o seu poema ganhe em performance, em subjetividade e em ambiguidade. Georges Bataille (2016, p. 177), em $A$ experiência interior, destaca que se

palavras como "cavalo" ou "manteiga" entram num poema, fazemno liberadas das preocupações interessadas. Por mais que essas palavras: "manteiga", "cavalo" sejam aplicadas a fins práticos, o uso que a poesia faz delas libera a vida humana desses fins.

\footnotetext{
${ }^{4}$ A relação entre a criança e o poeta será apresentada ao longo deste artigo tendo como base o texto freudiano "O poeta e o fantasiar", de 1908, presente no livro Arte, literatura e os artistas (2018).
} 
E conclui: "a poesia leva do conhecido ao desconhecido" (BATAILLE, 2016, p. 177, grifos do autor). O poético nos leva do desvelamento à ocultação, mas nela não se demora, pois nem permanece no desvelamento, próprio do olhar objetivo adulto, nem no ocultamento, próprio daquilo que o homem não consegue apreender, ver, enquanto linguagem, mas cruza esses dois caminhos, interliga-os, provocando naquele que lê o poema a sensação, por vezes incômoda, do infamiliar: "Infamiliar seria tudo o que deveria permanecer em segredo, oculto, mas que veio à tona" (FREUD, 2019, p. 45, grifos do autor).

Na poesia, vem à luz a arbitrariedade do signo linguístico que se encontrava oculta, ou recalcada, na presumida transparência da palavra em seu uso diário. Ou seja, a poesia assume o investimento arbitrário que fora recalcado na palavra em seu emprego cotidiano. É por meio da arbitrariedade da palavra manifesta na poesia que o sentimento infamiliar irrompe no leitor. Freud (2019, p. 33, grifo do autor), em $O$ infamiliar, nos assegura do diálogo que existe entre o não familiar, o terror, o desconhecido e o infamiliar, embora tais sensações não sejam sinônimas em si, mas quase antônimas, uma vez que, nas três primeiras, o que angustia é o novo que chega, o desconhecido que se revela, diferentemente do que ocorre com a sensação de infamiliaridade, na qual a angústia sobrevém do muito íntimo que permaneceu, por alguma razão, recalcado: "Como é possível, sob quais condições, o que é íntimo se tornar infamiliar, aterrorizante, é algo a ser demonstrado na sequência". O psicanalista, então, inicia uma investigação linguística acerca dos significados das palavras unheimlich (infamiliar) e heimlich (familiar). Em um primeiro momento, é estabelecida a oposição entre as duas palavras, o que, de certo modo, já era esperado: o familiar compreende tudo aquilo que é doméstico, conhecido, caseiro e aconchegante; já o infamiliar compreende o seu oposto, ou seja, o selvagem, o desconhecido, o estrangeiro e o que provoca mal-estar. Contudo, em um segundo momento, a palavra heimlich adquire o significado de segredo, aquilo que deve permanecer oculto, e não mais dado às vistas ou apresentado. Um exemplo bastante interessante desse desvio da palavra heimlich pode ser assim demonstrado: suponhamos uma cena, onde temos uma casa, o seu interior, e o espaço que a cerca, o seu exterior. Nessa cena, a palavra heimlich, para aqueles que estão dentro da casa, significa o doméstico, o apresentável, mas, para aqueles que estão fora da casa, o 
que é doméstico, heimlich, deve permanecer oculto, em segredo, para não suscitar o desejo de apropriação.

Nesse desvio do sentido, ou de ganho de sentido, a palavra heimlich barganha para si um significado que estava até então restrito ao campo semântico da palavra unheimlich, o campo do desconhecido, do estranho. Ao apresentar tal desvio, na usurpação do sentido daquilo que se encontra em segredo, a palavra heimlich se funde à palavra unheimlich: "Infamiliar é, de certa forma, um tipo de familiar" (FREUD, 2019, p. 49, grifo do autor). Aquilo que se pressupõe conhecido é, ao mesmo tempo, aquilo que se sabe desconhecido. $\mathrm{Ou}$, em uma inversão aqui apropriada, aquilo que se supõe desconhecido, na verdade, é o bastante conhecido. Presente na palavra infamiliar, temos a palavra familiar: in-familiar. Uma questão de prefixo que marca a presença da sensação conhecida, porém, recalcada: "O infamiliar é, então, também nesse caso, o que uma vez foi doméstico, o que há muito é familiar. Mas o prefixo de negação 'in-' [Un-] nessa palavra é a marca do recalcamento" (FREUD, 2019, p. 95, grifos do autor). Se a sensação se encontra recalcada é porque de algum modo essa sensação provocava angústia no ser, por exemplo, no caso de Nathanael, personagem do conto "O Homem da Areia", de E. T. A. Hoffmann, analisado por Freud em $O$ infamiliar. Em resumo, quando adulto, Nathanael se depara com o oculista Giuseppe Coppola, que de imediato lhe causa uma forte sensação de infamiliaridade ao apresentar-lhe diversos tipos de óculos. Essa sensação desconhecida, terrificante, remete-o, na verdade, a uma época precisa de sua infância, quando, na presença de seu pai e de um advogado amedrontador chamado Coppelius, ele supostamente tem os seus olhos ameaçados por este último, embora não saibamos se a ameaça fora real ou fantasiada. Mas o que marca realmente a criança, a sensação que permanece e que fora recalcada, é a ameaça da perda dos olhos, que é reativada pela presença do oculista Coppola. Segundo Freud (2019), em sua análise do conto, essa ameaça está associada também ao complexo de castração. Porém, não nos demoraremos nessa questão, pois é preciso seguir adiante, uma vez que o infamiliar poético nos espera.

Em Poeminha em língua de brincar, o infamiliar é a própria linguagem poética, ou melhor, a sensação infamiliar provocada no 
leitor adulto ${ }^{5}$ deriva da linguagem literária enquanto descentramento, desconstrução e movimento direcionado para si própria, jamais como um simples movimento-arremedo destinado a representar fidedignamente elementos de nossa realidade: "No poema, a linguagem nunca é real em nenhum dos momentos por onde passa, porquanto no poema a linguagem afirma-se como todo e sua essência, não tendo realidade senão nesse todo" (BLANCHOT, 1987, p. 39). No poema de Manoel de Barros, a criança-poeta "tinha no rosto um sonho de ave extraviada. / Falava em língua de ave e de criança" (BARROS, 2019, p. 7). Ou seja, a criançapoeta falava uma língua diferente daquela manejada pelos adultos, uma língua poética que, por sua vez, tornava-a um ser fora do mundo do bom senso e da lógica, tornava-a estrangeira, porém, nativa desse mundo real que a exilava: "Isso é Língua de brincar / é coisa-nada" (BARROS, 2019, p. 28), sentencia a Dona Lógica da Razão. Maurice Blanchot (1987), em O espaço literário, nos assegura que o poeta fala uma língua que ninguém mais fala, uma língua original, e que ele pertence a um mundo onde poucos podem nele habitar. É exatamente essa revelação da estrangeiridade da linguagem e do poeta que causa no leitor adulto a sensação de infamiliaridade. E o retorno do que antes estivera recalcado, a ambiguidade e a performatividade da palavra, que faz com que surja esse estranhamento tão forte, a ponto de fazer a Dona Lógica da Razão começar a "bostear", talvez porque se sinta intimidada diante da essência da linguagem, que seria o caos, ${ }^{6}$ mas um caos produtivo. Sejamos um pouco mais claros: a linguagem que manejamos é, em essência, arbitrária. Já nos lembrava Saussure que não há imediaticidade entre significante e significado, mas uma pretensa imediaticidade embasada em critérios sociais, políticos e culturais, por isso a proliferação das muitas línguas.

Em verdade, "nada de mais estranho para a árvore do que a palavra árvore, tal como a utiliza, não obstante, a linguagem cotidiana" (BLANCHOT, 1987, p. 33). Se, por um lado, a linguagem diária tenta

\footnotetext{
${ }^{5} \mathrm{~A}$ análise, aqui proposta, baseia-se no sentimento infamiliar provocado pelo poema no adulto. A existência, ou não, do sentimento infamiliar provocado pelo poema na criança demanda outras considerações que, oportunamente, serão desenvolvidas em outro texto. ${ }^{6}$ Caos enquanto movimento de potência da linguagem em sua arbitrariedade sem limitações no espaço poético. Na literatura, não havendo limites, a palavra pássaro, por exemplo, pode se referir a tudo menos ao animal pássaro como comumente a palavra pássaro em seu uso cotidiano se refere. Caos enquanto criatividade sem contenções, sem interdições e sem o fantasma da lógica.
} 
minimizar o caos provocado pela arbitrariedade do signo linguístico, sendo objetiva, racional e lógica para que uma ordem se estabeleça no todo social; por outro lado, a poesia deixa o caos linguístico ganhar corpo e múltiplas formas, deixando-o extravasar em desejo e prazer. Por duas vezes a palavra sonho surge no poema de Manoel de Barros para caracterizar a criança-poeta e uma única vez é mencionada a palavra sonhadas, derivação da palavra sonho, para caracterizar a sua linguagem caótica: "Isso é Língua de brincar e é idiotice de criança / pois frases são letras sonhadas, não têm peso" (BARROS, 2019, p. 20). Em "O poeta e o fantasiar", Freud (2018, p. 57) associa muito acertadamente o sonho e a fantasia ao desejo, e ainda melhor, associa-os à insatisfação:

Deve-se dizer que quem é feliz não fantasia, apenas o insatisfeito. Desejos insatisfeitos são as forças impulsionadoras [Triebekräfte] das fantasias, e toda fantasia individual é uma realização de desejo, uma correção da realidade insatisfatória.

Caso não houvesse a insatisfação com o mundo real que nos cerca, o poeta com certeza não fantasiaria e, consequentemente, não teríamos em mãos livros e mais livros nos quais mundos diversos originados pela insatisfação de seu criador nos são apresentados em forma de desejo, de desejo que provoca o prazer naquele que se aventura por esses mundos poéticos. $\mathrm{O}$ "sonho de ave extraviada" da criança-poeta é a realização de um desejo provocado pela insatisfação provinda da lógica do mundo real. É por isso que ela brinca, mas dispensa pensar; floreia, mas se recusa a transformar palavras em ideias. A criança-poeta elege a palavra enquanto brinquedo, enquanto moduladora da fantasia, do brincar constante, e não mais a palavra associada à realidade lógica do mundo adulto.

Enquanto brinquedo, enquanto palavra-brinquedo, a palavra poética se recusa ao enquadramento do bom senso e da lógica do mundo real. Seguindo idêntico caminho trilhado pela criança, o poeta também se recusa à lógica e ao bom senso da linguagem cotidiana, pois o poeta é aquele que abraça o caos essencial da linguagem na construção em fantasia de seu mundo poético:

O poeta faz algo semelhante à criança que brinca; ele cria um mundo de fantasia que leva a sério, ou seja, um mundo formado por grande mobilização afetiva, na medida em que se distingue rigidamente da realidade. (FREUD, 2018, p. 54) 
A criança e o poeta constroem mundos singulares a partir da insatisfação com o mundo real. A insatisfação, nesse caso, é criativa e produtiva, sendo o estado de insatisfação o gatilho para a criação poética e para o brincar infantil. Em Poeminha em lingua de brincar, como o próprio título já antecipa, a criança joga a todo instante com as possibilidades da língua, ela fantasia acordada, explora o não mais explorado pelo adulto: a potencialidade arbitrária da língua. A criança olha para o mundo real, mas o seu olhar inverte as categorias desse mundo, uma vez que ela renuncia ao seu bom senso para que o seu olhar ultrapasse a limitação da lógica na construção de seu mundo particular. Em seu olhar para fora, a criança faz um grande investimento de afetos, como nos lembra Freud (2018), sendo tal investimento uma das razões para que não menosprezemos o jogo infantil, como o faz terrivelmente a Dona Lógica da Razão na décima segunda estrofe do poema de Manoel de Barros (2019, p. 28):

Logo entrou a Dona Lógica da Razão e bosteou: / Mas lata não aguenta uma Tarde em cima dela, e / ademais a lata não tem espaço para caber uma / Tarde nela! / Isso é Língua de brincar / é coisa-nada.

Montaigne (2016, p. 149), em "Dos costumes e da inconveniência de mudar sem maiores cuidados as leis em vigor", texto presente em Ensaios, nos faz o seguinte alerta: "os jogos infantis devem julgar-se não apenas como divertimentos mas ainda como ações de importância".

Através de seu mundo em fantasia, a criança explora, ao avesso, o mundo real e joga com os adultos, das mais variadas e complexas formas, desenvolvendo, assim, a sua psique e os seus olhares: para o mundo, para o outro e para si própria. Porém, para se tornar adulta, a criança é forçada, pelas tendências que servem ao eu e pelas exigências morais do meio, a abandonar o jogo e a assumir a linguagem do adulto. Para tanto, é preciso que a criança recalque a linguagem enquanto caos, a linguagem essencialmente arbitrária, para aderir à linguagem enquanto lógica, enquanto instrumento, com o objetivo de que o seu caminhar pelo mundo real seja um caminhar útil, forçosamente utilitário: não há mais espaço para "idiotice de criança". Como observa Freud (2018), nem toda sensação recalcada tem uma base negativa, podendo muito bem vir a ter uma base positiva, como é o caso da criança e a sua linguagem poética. $\mathrm{O}$ adulto, ao se deparar com o poema, neste caso, com o Poeminha em 
língua de brincar, é invadido pelo sentimento do infamiliar, ou seja, pelo sentimento familiar que antes estivera recalcado, oculto. Semelhante ao que ocorrera a Nathanael, quando o oculista lhe apresentara diversos óculos, o leitor adulto, ao se ver exposto novamente à linguagem de base arbitrária, poética, é tomado por uma sensação bastante estranha, infamiliar, que o remete à infância, a uma época em que a linguagem estava desvinculada da lógica e do bom senso. Essa reativação da cena primária tanto pode lhe provocar, além da sensação de infamiliaridade, um movimento de dispersão e de fuga, quanto um movimento nostálgico, pelo qual o adulto se dará a oportunidade de mais uma vez abrir uma fenda na realidade e compactuar com a arbitrariedade do signo linguístico. Já o poeta, diferentemente do homem comum, mantém-se criança, sustentando a linguagem de essência arbitrária como a sua própria linguagem:

Não esqueçam que o destaque, talvez estranho, às lembranças infantis na vida do poeta deriva, em última instância, da pressuposição de que a criação literária, como o sonho diurno, é uma continuação e uma substituição, a uma só vez, das brincadeiras infantis. (FREUD, 2018, p. 62-63)

Desse modo, o poetar e o brincar constituem-se como atividades similares em que a linguagem poética, sem o peso da lógica e do bom senso, é o suporte que origina os seus mundos particulares. É através dela também que o leitor poderá atingir a experiência do prazer de que escreve Bataille (2016, p. 37), em A experiência interior: "Chamo experiência uma viagem ao extremo do possível do homem". Um prazer que, por meio do orifício do corpo textual poético, dá a ver ao leitor um mundo em desvario, em jouissance:

a linguagem literária - expressão de desejos ocultos, da vida obscura - é a perversão da linguagem um pouco mais até do que o erotismo é a perversão das funções sexuais. Daí o "terror" que, no fim, impera "nas letras" (BATAILLE, 2016, p. 193).

Em diálogo cerrado com Freud, Bataille (2016, p. 35) arremata: "Se a poesia introduz o estranho, ela o faz pela via do familiar. O poético é o familiar dissolvendo-se no estranho, e nós mesmos com ele". Na quinta e sexta estrofes de Poeminha em língua de brincar, a criança-poeta de Manoel de Barros (2019, p. 14-17) nos diz: "Contou para a turma da roda que certa rã saltara / sobre uma frase dele / e que a frase nem 
arriou. // Decerto não arriou porque não tinha nenhuma / palavra podre nela". Nesses versos, o que se dá a ver não é a palavra rã que representa o animal rã em nosso mundo real, mas sim uma palavra-rã que salta nos versos seguintes da criança-poeta e que extrapola o limite do real, do verossímil e da lógica. Uma palavra-rã que olha para o leitor adulto e que salta em sua direção, na direção daquilo que ele próprio recalcou. Caso o leitor não se assuste e fuja, ele poderá experienciar essa sensação única provinda da palavra poética, esse prazer perverso que somente o literário pode liberar.

Como pudemos observar ao longo do desenvolvimento deste artigo, a criança-poeta instaura uma nova ordem linguística na construção do seu mundo poético, uma ordem que, como vimos, é diversas vezes contestada pela Dona Lógica da Razão, que, por sua vez, só pôde ganhar corpo e agir como um ente na poesia que tanto refuta e maldiz: "Isso é Língua de brincar / é coisa-nada" (BARROS, 2019, p. 28). Ao que a criança-poeta sentencia: "O menino sentenciou: / Se o Nada desaparecer a poesia acaba" (BARROS, 2019, p. 30). Em uma bela jogada lógica, que descentra a própria Lógica, a criança-poeta reafirma, através do "Nada", a soberania do espaço literário: "Pois bem, ainda é melhor: o silêncio, o nada, isso é a essência da literatura" (BLANCHOT, 1997, p. 298, grifo do autor). Na perspectiva blanchotiana, em seu texto "A literatura e o direito à morte", presente no livro A parte do fogo, o "nada" é o tudo. O nada enquanto potência da palavra poética de tudo dizer e de tudo desdizer, de tudo afirmar e de tudo negar, de tudo transformar e de tudo ressignificar. O nada é o abandono da norma, da lei, da lógica, da racionalidade e do bom senso empreendido pelo poeta e pela criançapoeta. O nada é, também, palavra, mas palavra desterritorializada, desconstruída e reorganizada em uma nova estrutura de linguagem, uma estrutura poética-caótica-produtiva que faz a Tarde se sentar sobre uma lata (BARROS, 2019).

\section{$O$ arrebatamento pela via do infamiliar}

Entre a criança-poeta, de Manoel de Barros, e a criança-arrebatada, de Maurice Blanchot, há o olhar (para o) infamiliar. Em "(Uma cena primitiva?)", a criança não faz poesia, não joga com a palavra, não fabrica um mundo próprio, não está no processo do que provocará o infamiliar no leitor adulto: o alto investimento de afetos na brincadeira 
com a palavra em sua plena arbitrariedade. Dessa criança, pelo contrário, o que se percebe é um certo tédio, uma insatisfação que, em um primeiro momento, não produz fantasias, muito menos sonhos. A essa criança, aparentemente sem desejo pelo que a cerca, nada interessa. Porém, ao olhar o comum das coisas, a criança sofre uma epifania. Ao olhar para o céu, o mesmo céu de todos os tediosos dias, não deixemos de destacar a ênfase que é dada ao adjetivo "mesmo" no fragmento blanchotiano, a criança se dá conta de algo bastante violento: a presença do infamiliar nas coisas cotidianas, no mundo enquanto tal. $O$ choque dessa visão lhe revela que nas coisas do mundo o que está manifesto desde sempre, na verdade, é uma ausência e não uma presença, como nos quer fazer crer o homem e a sua rotina escandalosamente cruel, "que nos dá a ilusão, a segurança do imediato, o qual, contudo, nada é senão o rotineiro" (BLANCHOT, 1987, p. 34). Essa ausência nas coisas é uma derivação da ausência presente na linguagem que nomeia as coisas, como nos lembra Blanchot (1987, p. 33) na passagem sobre a palavra árvore anteriormente mencionada. Se a palavra não nos entrega o ser, mas a ausência do ser, o mundo por ela nomeado é também pura ausência. O mundo em ausência:

A palavra me dá o que ela significa, mas primeiro o suprime. Para que eu possa dizer: essa mulher, é preciso que de uma maneira ou de outra eu lhe retire sua realidade de carne e osso, que a torne ausente e a aniquile. A palavra me dá o ser, mas ele me chegará privado de ser. Ela é a ausência desse ser, seu nada, o que resta dele quando perdeu o ser, isto é, o único fato que ele não é. Desse ponto de vista, falar é um direito estranho. (BLANCHOT, 1997, p. 310-311, grifo do autor).

Está mais uma vez presente na linguagem a violência do infamiliar. É nela que se concentra tanto o elemento recalcado quanto a volta desse. E essa revelação arrebatadora, do in-familiar, se deixa ver em momentos nos quais estamos fora do circuito tramado pela rotina diária, por exemplo, quando estamos nos aventurando pela literatura ou quando estamos entediados. Estar entediado é o instante em que todas as seduções do mundo real fracassam, caem por terra, apresentam-se enfadonhas. E, desse enfado, o mundo se revela pobre, nauseante e ameaçador. A partir de então, uma fresta se abre, um rasgo se faz no cotidiano, e o mundo se revela em sua completa ausência. Esse mundo 
que nos comunica a fala comum não passa do longínquo velado, $o$ absolutamente estranho que se faz passar por habitual, o insólito que tomamos por rotineiro graças a esse véu que é a linguagem e a esse hábito da ilusão das palavras (BLANCHOT, 1987, p. 34).

Como Blanchot (1987) nos auxilia a perceber, em "A solidão essencial", texto que se encontra em $O$ espaço literário, o mundo está sob um véu linguístico que nos ilude, que encobre o estranho e o insólito (o infamiliar) na própria construção do habitual e do rotineiro (no familiar). Embora esse véu seja bastante resistente e impositivo, ele não o é totalmente, como atesta a criança blanchotiana ao se deparar com o mesmo, porém diferente, céu de todos os dias: "O que se passa em seguida: o céu, o mesmo céu, de repente aberto, absolutamente escuro e absolutamente vazio" (BLANCHOT, 1980, p. 117, grifo do autor). Dessa fenda, o que irrompe por meio do sentimento infamiliar provocado pelas coisas cotidianas não poderá jamais ser proferido, apenas guardado enquanto segredo: "Ele não diz nada. Ele viverá de agora em diante no segredo" (BLANCHOT, 1980, p. 117, grifo do autor). Podemos nos questionar sobre o que o impede de testemunhar e, consequentemente, o que o força a manter segredo sobre o que lhe ocorrera: " $a$ alegria devastadora que ele somente poderá testemunhar pelas lágrimas, uma profusão sem fim de lágrimas" (BLANCHOT, 1980, p. 117, grifo do autor).

A resposta estaria, o que não mais nos surpreende, na própria linguagem, seguindo duas vias: a do testemunho e a da palavra. Jacques Derrida (1998), em Demeure, nos alerta para a complexa estrutura do testemunho. Por um lado, o testemunho é inseparável de seu caráter ficcional, que Derrida nomeia de literatura, uma vez que dar testemunho é produzir texto, é tentar recriar uma cena testemunhada, e, como não será possível reproduzi-la literalmente, a ficção entra como modo de costura dos fatos esquecidos da cena testemunhada. Por outro lado, o testemunho, embora testemunhável, não escapa ao segredo, pois a cena testemunhada tende a ser algo único, um acontecimento que rompe com o cotidiano e com a lógica de nossa rotina, não podendo ser jamais reproduzida ou encenada novamente. Assim, o ato de testemunhar estaria em uma constante tensão entre a ficção e o segredo, entre a possibilidade e a impossibilidade do dizer: 
Para permanecer testemunho, ele deve então se deixar assombrar. Deve se deixar parasitar por aquilo mesmo que ele exclui de seu foro interior, a possibilidade, ao menos, da literatura. É sobre esse limite indecidível que tentaremos nos demorar. [...] Limite impossível, então. Insustentável. É ele que condena o testemunho ao segredo; ele o intima a se demorar segredo ali mesmo onde se torna manifesto e público. Somente posso testemunhar, no sentido estrito dessa palavra, no instante em que aquilo que testemunho ninguém pode testemunhá-lo em meu lugar. Aquilo que testemunho é primeiro, imediatamente, meu segredo, ele permanece reservado a mim. Devo poder guardar segredo daquilo mesmo que testemunho; é a condição do testemunho no sentido estrito, e é por isso que nunca se poderá demonstrar, no sentido da prova teórica e do julgamento determinante, que um perjúrio ou uma mentira tiveram efetivamente lugar. A própria confissão não é o bastante. (DERRIDA, 1998, p. 31-22, grifo do autor, tradução nossa). ${ }^{7}$

Em “A literatura e o direito à morte", Blanchot (1997, p. 314, grifo do autor) afirma categoricamente: "A palavra não basta para a verdade que ela contém". A verdade, que tende a romper a sua estrutura e a qual os homens temem que venha à luz do dia, é a ausência das coisas, ou melhor, é a impossibilidade de reter qualquer presença das coisas no corpo da palavra: "A linguagem só começa com o vazio; nenhuma plenitude, nenhuma certeza, fala; para quem se expressa falta algo essencial" (BLANCHOT, 1997, p. 312, grifo do autor). Deve-se a essa certa intransigência da linguagem o fato de a criança blanchotiana não poder testemunhar o arrebatamento provocado pelo infamiliar presente

\footnotetext{
${ }^{7}$ No original: "Pour rester témoignage, il doit donc se laisser hanter. Il doit se laisser parasiter par cela même qu'il exclut de son for intérieur, la possibilité, au moins, de la littérature. C'est sur cette limite indécidable que nous allons essayer de demeurer. [...] Limite impossible, donc. Intenable. C'est elle qui à demeure voue le témoignage au secret; elle lui enjoint de demeurer secret là même où il rend manifeste et public. Je ne peux témoigner, au sens strict de ce mot, qu'à l'instant où ce dont je témoigne, personne ne peut en témoigner à ma place. Ce dont je témoigne est d'abord, à l'instant, mon secret, il reste à moi réservé. Je dois pouvoir garder secret cela même dont je témoigne; c'est la condition du témoignage au sens strict, et c'est pourquoi on ne pourra jamais démontrer, au sens de la preuve théorique et du jugement déterminant, qu'un parjure ou un mensonge ont effectivement eu lieu. L'aveu même n'y suffit pas."
} 
nas coisas familiares de seu cotidiano. A criança vê, olha e observa a ausência presente no mundo, embora não possa testemunhá-la:

uma tal ausência como se tudo já estivesse lá desde sempre e para sempre perdido, a tal ponto que nela se afirma e se dissipa o saber vertiginoso que nada é o que existe, e sobretudo nada existe para além dela. (BLANCHOT, 1980, p. 117, grifo do autor)

Se pararmos um momento para pensar, constataremos que o nosso real é, a bem da verdade, um real forjado e imposto por nosso meio familiar, por nossa sociedade, por nossas leis, por nossas imaginações e fantasias, jamais sendo um real verdadeiro, sobretudo porque a linguagem que nos possibilitaria definir esse real é o que nos impossibilita defini-lo, pois a linguagem não nos entrega o real, mas a ausência desse real: "Na verdade, o mundo sensível - nosso mundo - nada tem de especialmente nu, ele é totalmente forjado e constituído por relações que remetem imediatamente à ditadura da figura do real" (BADIOU, 2017, p. 15). Por essa razão, de real no mundo, temos apenas a sua ausência de real que se dá a ver na própria linguagem. Em "(Uma cena primitiva?)", o infamiliar, que transtorna a criança a ponto de fazê-la "testemunhar pelas lágrimas", é definitivamente a ausência irrefutável presente nas coisas, que, por sua vez, fora recalcada pela pretensa organicidade do mundo: "uma tal ausência como se tudo já estivesse lá desde sempre e para sempre perdido" (BLANCHOT, 1980, p. 117, grifo do autor).

Acredito que o sintagma "(Uma cena primitiva?)", que inicia o fragmento blanchotiano em análise, tenha de algum modo chamado a atenção daqueles que conhecem a obra de Freud, pois não é de todo absurdo fazermos uma relação ou pretendermos fazer um diálogo entre os dois autores.

A título de curiosidade, do que podemos apreender da quarta parte, "O sonho e a cena primária", do texto "História de uma neurose infantil ['O homem dos lobos']", de Freud (2010), o conceito de cena primária se refere a uma cena original surgida geralmente em tenra idade, antes dos quatro ou cinco anos de idade da criança, e que possui um papel fundamental em seu desenvolvimento sexual, psicológico e social. Nesse texto, Freud (2010) relata o caso de um de seus pacientes: as suas graves inibições sociais, o seu prazer sexual associado a uma única posição sexual e a sua aterrorizada relação com a figura masculina que, ao longo da análise, se mostrou como uma derivação do medo da 
figura paterna. Além dessas angústias, o analisando era constantemente atormentado por um sonho específico: um sonho com seis ou sete lobos. No decorrer da análise, Freud e o analisando constroem a cena primária que fora recalcada pelo paciente: com um ano e meio, o analisando "foi testemunha de um coito a tergo [por trás] repetido três vezes, [ele] pôde ver os genitais da mãe e o membro do pai, e compreendeu tanto o fato como a sua significação" (FREUD, 2010, p. 52-53, grifo do autor). Essa visão do coito apenas será compreendida em sua completude pelo paciente aos quatro anos de idade, quando passa a sonhar com os lobos, quando começa a explorar a sua genitália, excitando-se, e quando inicia um trabalho de pesquisa sobre as relações sexuais entre os animais. Essa cena primária, como dirá Freud (2010), se tornou a origem e, ao mesmo tempo, a resposta para as questões e para o sonho que tanto afligiram o analisando ao longo de sua vida. É certo que apenas na análise o paciente pôde compreender como de fato a cena do coito entre os seus pais, a cena primeiríssima, reverberou em seu íntimo:

Com um ano e meio a criança recebe uma impressão a que não pode reagir o bastante, só a compreende, só é comovida por ela na sua revivescência aos quatro anos, e somente na análise, duas décadas depois, pode apreender, com sua atividade mental consciente, o que ocorreu então dentro de si. (FREUD, 2010, p. 63).

Em relação ao caso apresentado por Freud em "O homem dos lobos" e ao fragmento blanchotiano de "(Uma cena primitiva?)", fora a semelhança entre os sintagmas "cena primitiva" e "cena primária", nada mais poderemos estabelecer com precisão, pois Blanchot dificulta, através da torção fragmentária de seu livro, uma relação mais estreita entre o conceito freudiano e o seu sintagma textual. Há, porém, duas possíveis interpretações para o caso Blanchot. A primeira interpretação, talvez Freud dissesse se tratar de um chiste blanchotiano: ao encabeçar o seu fragmento com o sintagma "uma cena primitiva", Blanchot induz o seu leitor conhecedor da obra freudiana a fazer de imediato uma relação com o conceito do psicanalista, quando, na verdade, o seu sintagma seria apenas um trompe-l'œil, uma ilusão que mascara a problemática de seu fragmento, que, como vimos, se refere à ausência nas coisas que constituem o mundo, uma ausência derivada da linguagem que o nomeia. A segunda interpretação: a visão da criança poderia ser, de fato, uma cena 
primária, porém, nos fragmentos anteriores e seguintes, a criança não é retomada em sua fase adulta, não nos é possível estabelecer se houve trauma ou não após a visão do "céu, o mesmo céu". O sintagma "(Uma cena primitiva?)" é retomado mais duas vezes ao longo de L'écriture $d u$ désastre, mas nada da vida adulta da criança nos é revelado. Ou seja, desse modo, não nos é possível legitimar "(Uma cena primitiva?)" como sendo uma cena primária no sentido dos estudos freudianos.

Talvez seja esse o motivo da presença do ponto de interrogação no sintagma blanchotiano, que não invalida, pelo contrário, reforça o seu caráter de blague ou, para os freudianos, de humor infeliz, pois os induzem ao erro momentâneo na compreensão do fragmento: "Aquele que critica ou rejeita o jogo, já entrou no jogo" (BLANCHOT, 1980, p. 21). É verdade, rejeitando ou não, ao lermos o poema de Manoel de Barros e o fragmento poético de Maurice Blanchot, já nos encontramos na posição de jogadores de um jogo de linguagem que tenderá sempre a nos fazer perder, como em um jogo viciado, pois a linguagem literária, que se deixa ver pela via do in-familiar, seduz perversamente o seu leitor, deixando-o, através de seu canto infamiliar, se abandonar aos Infernos poéticos.

\section{Referências}

BADIOU, Alain. Em busca do real perdido. Tradução de Fernando Scheibe. Belo Horizonte: Autêntica Editora, 2017.

BARROS, Manoel de. Poeminha em língua de brincar. São Paulo: Companhia das Letrinhas, 2019.

BATAILLE, Georges. A experiência interior: seguida de Método de meditação e Postscriptum 1953. Tradução de Fernando Scheibe. Belo Horizonte: Autêntica Editora, 2016.

BLANCHOT, Maurice. A parte do fogo. Tradução de Ana Maria Scherer. Rio de Janeiro: Editora Rocco, 1997.

BLANCHOT, Maurice. L'écriture du désastre. Paris: Gallimard, 1980.

BLANCHOT, Maurice. O espaço literário. Tradução de Álvaro Cabral. Rio de Janeiro: Editora Rocco, 1987. 
DERRIDA, Jacques. Demeure: Maurice Blanchot. Paris: Éditions Galilée, 1998.

FREUD, Sigmund. Arte, literatura e os artistas. Tradução de Ernani Chaves. Belo Horizonte: Autêntica Editora, 2018.

FREUD, Sigmund. História de uma neurose infantil: ["O homem dos lobos"], Além do princípio do prazer e outros textos (1917-1920). Tradução de Paulo César de Souza. São Paulo: Companhia das Letras, 2010. (Obras Completas, v. 14).

FREUD, Sigmund. $O$ infamiliar [Das Unheimliche]; seguido de $O$ Homem da Areia, de E. T. A. Hoffmann. Tradução de Ernani Chaves, Pedro Heliodoro Tavares e Romero Freitas. Belo Horizonte: Autêntica Editora, 2019. (Obras Incompletas de Sigmund Freud).

MONTAIGNE, Michel de. Ensaios. Tradução e notas de Sérgio Milliet. São Paulo: Editora 34, 2016.

ROUDINESCO, Elisabeth. Dicionário amoroso da psicanálise. Tradução de André Telles. Rio de Janeiro: Zahar, 2019.

SÓFOCLES. Édipo Rei de Sófocles. Tradução de Trajano Vieira. São Paulo: Perspectiva, 2016. 